\title{
Digitality in Ethics Learning Units
}

\author{
Claudia Dörfer¹, Maria Magdalena Madrigal Lozano², \\ Gabriela Soledad Ulloa Duque ${ }^{3}$, Jesús Osorio Calderon ${ }^{4}$
}

\author{
${ }^{1}$ Dr. edu., Corresponding author, Autonomous University of Nuevo León, Faculty of Public Accounting and \\ Administration, School of Business, Mexico, ORCID ID: 0000-0002-9231-1898 \\ ${ }^{1}$ Dr. edu., Autonomous University of Nuevo León, Faculty of Public Accounting and Administration, \\ School of Business, Mexico, ORCID ID: 0000-0001-6702-3803 \\ ${ }^{1}$ M.C., Autonomous University of Nuevo León, Faculty of Public Accounting and Administration, \\ School of Business, Mexico, ORCID ID: 0000-0003-4597-4207 \\ ${ }^{1}$ Dr., Autonomous University of Nuevo León, Faculty of Public Accounting and Administration, \\ School of Business, Mexico, ORCID ID: 0000-0003-4862-8684 \\ Email: claudia.doerfer@uanl.edu.mx,maria.madrigallz@uanl.edu.mx, \\ GABRIELA.ULLOADQ@uanl.edu.mx, jesus.osoriocd@uanl.edu.mx
}

\begin{abstract}
This study constructed and validated an attitude scale for ethics learning units using technology among undergraduate students in a Mexican business school. We sought to determine whether the motivation and usage of a learning-management system (LMS) combined with learning elements in mobile applications and the active support of instructor increases motivation, willingness to learn, learning benefit, and satisfaction in ethics learning units. The approach of this study is quantitative, transversal, and not experimental and used a sample $(\mathrm{N}=227)$ of international business, administration, and public accounting undergraduate students. The self-reported data from students were obtained from anonymous questionnaire surveys. It is a pilot study and the sample presented is relatively small, which limits the applicability of the findings. Because the instrument is a self-support and is anonymous, participants can respond in socially desirable terms, remaining neutral in the response.
\end{abstract}

Keywords: Business Ethics, Digitality, Higher Education.

\section{Introduction}

The effects of pandemic are visible in the accelerated process of digitalisation at universities, which has affected students, teachers and all organisational processes involved. According to the United Nations Educational, Scientific and Cultural Organization (2020), from February 16, 2020 to December 5 of the same year in Mexico, $73 \%$ of this time schools have remained closed, thus forcing the switch to digital. Digitalisation permeates real and virtual learning places: people's relationships conducted through very different media are a matter of course, especially for young people and a separation of real and virtual learning places no longer corresponds to students' living environment. In this context, the business school of a public university in north-east Mexico set an objective to offer its four programmes for undergraduates (Bachelor of Administration, Public Accounting, Bachelor of International Business and Bachelor of Information Technology) in digital modality for distance learning. Ethics, one of the learning units for undergraduates, is an obligatory subject in the general course for all disciplines. Student motivation is often limited and without great interest, reduced to passing the subject.

The main study of the present paper explores the motivation, perceptions and attitudes of business students (accounting, management, and international business) towards this ethics-learning unit in a Mexican public university. A questionnaire survey was applied to the Mexican business students to assess these variables. It is important to note, however, that this work does not clarify students' ethical behaviour, but rather their attitude towards the course on the subject of ethics in an online mode. We based our study on the hypothesis that using a learning management system (LMS) combined with mobile technology and the active support of the instructor increases the motivation, willingness to learn, learning benefit and satisfaction of the students in the ethics-learning unit. The guiding concepts for this work are described further below.

\section{Motivation and self-directed learning}

In all educational settings, intrinsic and extrinsic motivation are both relevant for the learning, wellbeing and academic effort of students. Deci and Ryan's (2000) self-determination theory states, "intrinsic 
motivation is likely responsible for the preponderance of human learning across the life span, as opposed to externally mandated learning and instruction" (4).

The principal characteristics of SDL as a learning concept have been studied in numerous investigations in the context of adult learning and higher education since 1961 by Houle , Tough (1971), Knowles (1975) as an individual initiated process with personal requirements, objectives and resources that allows students to find their right ways to learn and assesses their results. In studies with business students indicate that online learners use learning strategies flexible, depends on organization of learning units, decide for themselves to control study time effectively and obtain support from others (Tseng et al., 2019; Kimmel et al., 2020).

Ryan and Deci (2019) claim out that persons adopt and hold diverse objectives in their lives, influenced by different aspects, and in self-directed-theory "it became evident that different life goals allow to satisfy basic needs differently, and therefore, influence well-being in systematic ways" (137).

Increased student satisfaction and positive attitudes towards technology use depend on individual beliefs, expectations and self-confidence in students' own abilities, emotions and personal interests (Arrosagaray et al., 2019; Plews, 2017).

\section{Attitude and Collaborativism}

Kerlinger and Lee (2002) have argued, "an attitude is an organized predisposition to think, feel, perceive and behave toward a cognitive referent or object" (648). Student engagement and attitude can be improved as result of technology, interest, confidence and relationships with colleagues and instructors (Bond et al., 2020, 5).

Harasim (2017) point out that online collaborative learning (OCL) denotes cooperative dialogue, awareness and understanding assisted by educational applications facilitated by the internet that enables the individual learning process. "Collaborativism emphasizes processes that lead to both conceptual understanding and knowledge products. It is based on peer discourse that is informed by the processes and resources of the knowledge community and facilitated by the instructor as a representative of that knowledge community. Most commonly, the discourse is text-based and asynchronous, taking place in a web-based discussion forum or computer conferencing system" (Harasim, 2017, 117).

\section{Method}

\section{Design and sample}

This study uses a mixed, exploratory, transversal and not experimental approach. The sample consisted of students $(\mathrm{N}=227)$ studying international business at a university in northeast Mexico. The sample was chosen based on accessibility to students in the obligatory ethics and society learning unit in the elearning environment, which is part of the final phase of their course; non-probabilistic and decisional sampling was used. Students were contacted in May 2020 through the learning platform and given a link to a Google form. A total of 227 students responded and took part in this study from the January-June 2020 semester. The data obtained from the surveys were stored in the Excel for Windows program, then transferred and analysed with IBM-SPSS version 21.

\section{Scale Development}

The questionnaire is a 5-point Likert scale from 1 (strongly disagree) to 5 (strongly agree). Questions were not written in the same direction, but required codification such that a higher score was related to a more positive motivation or attitude perceived. For scale development, we used extraction by principal components and component rotation (Varimax) to define the scale.

\section{Purpose}

The construction and validation of the content and constructs in the scale for attitude towards ethics learning units using technology in undergraduate students in a Mexican business school had the following partial goals:

(1) to create and apply the attitude scale towards ethics learning units using different technology;

(2) to determine the construct validity of the scale with factorial analysis;

(3) to determine the validity of the total content using Cronbach's alpha; and

(4) to determine the validity of the subscales using Cronbach's alpha. 


\section{Findings}

The instrument was an anonymous self-reporting questionnaire with 64 items, including 4 open answers related to demographic characteristics and 5 open-answer questions related to perceptions about the influence and use of different technologies such as the LMS, mobile technology for group communication and concept learning, discussion forums, short essays combined with the development of final project in small group work, perception of benefits from professional help and feedback by instructor during the learning processes. This was also related to motivation for ethical behaviour in private and professional life. Descriptive statistics were used with simple content analysis.

The questionnaire was answered by 227 students $(100 \%)$ in three undergraduate level degree courses; $64.3 \%$ were female and $35.7 \%$ male, with an age range of 20 to 40 years old. Table 1 illustrates the distribution of the demographic characteristics. All students were in the latter stages of their undergraduate career.

Table 1. Socio-demographic Profile

\begin{tabular}{ccc}
\hline Variables & Frequency & $\%$ \\
\hline Gender & 146 & 64.3 \\
Female & 81 & 35.7 \\
Male & 227 & 100.0 \\
Total & & \\
Grade level & 227 & 100.0 \\
Undergraduates & & \\
University career & 80 & 35.2 \\
Accounting & 51 & 22.5 \\
International Business & 96 & 42.3 \\
Management & & \\
\hline
\end{tabular}

Source: own

The principal component analysis revealed five components: motivation, disposition, benefits, accessibility and support with 18 items. We determined the construct validity of the scale with factor analysis, with a KMO value of .789 . 
Image 1. Rotated component matrix

Matriz de componentes rotados ${ }^{\mathrm{a}}$

\begin{tabular}{|c|c|c|c|c|c|}
\hline & \multicolumn{5}{|c|}{ Componente } \\
\hline & 1 & 2 & 3 & 4 & 5 \\
\hline Mot1 & -.083 & .797 & -.004 & .193 & .261 \\
\hline Mot2 & -.068 & .720 & -.010 & .034 & .347 \\
\hline Mot3 & -.048 & .858 & .025 & .112 & .236 \\
\hline Mot5 & -.017 & .847 & .021 & .080 & .016 \\
\hline Disp2 & .003 & .112 & .015 & .906 & -.049 \\
\hline Disp3 & .025 & .052 & .047 & .911 & .060 \\
\hline Disp4 & .016 & .194 & .000 & .891 & .051 \\
\hline Util3 & -.034 & .254 & .052 & .104 & .616 \\
\hline Util4 & -.069 & .109 & .005 & -.144 & .857 \\
\hline Util6 & -.025 & .298 & .001 & .095 & .729 \\
\hline Acce 1 & .928 & -.049 & -.139 & -.022 & -.079 \\
\hline Acce 2 & .917 & -.071 & -.211 & .034 & .017 \\
\hline Acce 3 & .972 & -.019 & -.009 & .003 & -.060 \\
\hline Acce 4 & .905 & -.065 & -.204 & .031 & -.023 \\
\hline Acce 5 & .938 & -.032 & -.089 & .009 & -.044 \\
\hline Apo2 & -166 & .032 & .930 & -.009 & -.026 \\
\hline Apo3 & -190 & -.005 & .958 & .060 & .048 \\
\hline Ap0 4 & -.162 & .003 & .933 & .020 & .043 \\
\hline
\end{tabular}

Método de extracción: Análisis de componentes principales. Método de rotación: Normalización Varimax con Kaiser.

a. La rotación ha convergido en 5 iteraciones.

Source: own with IBM-SPSS, ver. 21

Table 2 presents the results of the Cronbach's alpha coefficient obtained from analysis performed on the five subscales and answered by the 227 participants. The benefits factor $(\alpha=.600)$ reveals a lower reliability than other factors: the motivation factor obtained $\alpha=.862$; disposition, $\alpha=.900$; supports, $\alpha=$ .914 ; and accessibility, $\alpha=.968$.

Table 2. Subscale Consistency

\begin{tabular}{ccc}
\hline Subscale & Items & $\alpha$ \\
\hline Motivation & 4 & 862 \\
Disposition & 3 & .900 \\
Benefits & 5 & .600 \\
Accessibility & 5 & .968 \\
Support & 4 & .914 \\
\hline
\end{tabular}

Source: own

Cronbach's alpha is used to assess the dimensionality of a set of elements as a measure of the degree to which all variables on the scale are positively related to each other. The reliability of the scale as a whole, Cronbach's $\alpha=.765$, is sufficient considering the total rate. 


\section{Results, Conclusions and Recommendations}

We affirmed that the LMS with mobile technology and active support by instructor increases motivation for SDL and learning satisfaction in an ethics-learning unit in a distance-learning course. The goal of the study was to create an attitude scale and measure how teaching and learning resources such as the LMS, mobile technology, forums and interaction with the instructor influence motivation and disposition towards ethics learning units. It is essential for student motivation that observations are provided on the work delivered with recommendations for improvement in future works, particularly when combined with constant feedback from the instructor. Improvements in theoretical and concept learning permit suggest that LMS and mobile applications may have an impact on personal benefits and learning motivation for students who use it actively. That collective work using digital technologies motivates learning is not novel, nor are support and feedback from the instructor obsolete in increasing motivation towards learning and a successful learning process.

The findings of positive motivation and disposition towards learning units were significant for other subjects as well, including the integration of corporate and social responsibility and the incorporation of sustainability in the curricula of careers related to business, accounting, administration or information technology. Going one step further, models from Ajzen and Fishbein (1980) show when and why attitudes and values are or are not conveyed in actual behaviour. To behave in congruence with a set of values, one must first have a positive attitude towards this behaviour, the social environment must support the value and the person must also be able to implement the value. This means that if attitudes towards behaviour, the environment and the will to implement are negative, attitudes into behaviour are not implemented.

The small sample size and self-report instrument (participants may respond in socially desirable terms) are limitations of this study. The findings of this study may not be generalisable and application on a larger sample is required for scale confirmation.

\section{Acknowledgement}

This article was presented at the 6th International Conference on Lifelong Education and Leadership for all, ICLEL, July 16th - 18th 2020, Sakarya University, Turkey.

\section{References}

Ajzen, I., \& Fishbein, M. (1980). Understanding attitudes and predicting social behavior. Prentice Hall.

Arrosagaray, M., González-Peiteado., M., Pino-Juste, M., \& Rodríguez-López, B. (2019). A comparative study of Spanish adult students' attitudes to ICT in classroom, blended and distance learning modes. Computers and Education, 134, 3-40. https://doi.org/10.1016/j.compedu.2019.01.016.

Bond, M., Buntins, K., Bedenlier, S., Zawacki-Richter, O., \& Kerres, M. (2020). Mapping research in student engagement and educational technology in higher education: A systematic evidence map. International Journal of Educational Technology in Higher Education, (17)2. https://doi.org/10.1186/s41239-019-0176-8.

Harasim, L. (2017). Learning theory and online technologies (2nd ed.). Taylor \& Francis. Kindle Version. Houle, C. (1961). The inquiring mind. Madison. University of Wisconsin Press.

Kimmel, S., Trouard, S. \& Robbins, R. (2020). I Can't Get No (Grade) Satisfaction: Self-regulated Learning and Success in a School of Business. Business Education Innovation Journal 12(1).

Knowles, M.S. (1975). Self-directed learning: A guide for learners and teachers. Prentice-Hall.

Plews, R. (2017). Self-direction in online learning: The student experience. International Journal of SelfDirected Learning, 14(1), 37-57. Access: https://docs.wixstatic.com/ugd/dfdeaf_385a2e4d19254f968487b6058464e00c.pdf.

Ryan, R.M., \& Deci, E.L. (2019). Chapter four: Brick by brick: The origins, development, and future of selfdetermination theory. In A. J. Elliot (Ed.), Advances in motivation science, (vol. 6, pp. 111-156). Elsevier. https://doi.org/10.1016/bs.adms.2019.01.001.

Ryan, R.M. \& Deci, E.L. (2020). Intrinsic and extrinsic motivation from a self-determination theory perspective: Definitions, theory, practices, and future directions. Contemporary Educational Psychology, 61, 101860. https://doi.org/10.1016/j.cedpsych.2020.101860.

Tough, A. (1971). The adult's learning projects: A fresh approach to theory and practice in adult education. Toronto. Ontario Institute for Studies in Education.

Tseng, H., Yi, X., \& Yeh, H.T. (2019). Learning-related soft skills among online business students in higher education: Grade level and managerial role differences in self-regulation motivation, and social skill. Comupters in Human Behavior, (95), 179-186. https://doi.org/10.1016/j.chb.2018.11.035.

United Nations Educational, Scientific and Cultural Organization. (2020). COVID-19 Impact on Education. https://en.unesco.org/covid19/educationresponse 